REVISTA ANDALUZA DE ANTROPOLOGÍA.

NÚMERO 9: LA REPRESENTACIÓN DE LAS CULTURAS EN LA MUSEOLOGÍA ANTROPOLÓGICA DEL ESTADO ESPAÑOL

SEPTIEMBRE DE 2015

ISSN 2174-6796

[pp. 211-215]

http://dx.doi.org/10.12795/RAA.2015.109.09

\title{
PORTELLI, STEFANO (2015). La ciudad horizontal. Urbanismo y resistencia en un barrio de casas baratas de Barcelona. Barcelona: Ediciones Bellaterra, 489 pp.
}

\section{Beltrán Roca Martínez \\ Universidad de Sevilla}

En La ciudad horizontal Portelli analiza los conflictos urbanos en Bon Pastor, un barrio popular de Barcelona, poblado principalmente por población procedente de Murcia en la década de 1920. La historia de los habitantes del barrio es una historia de conflicto, opresión y resistencia. En sus orígenes fue un enclave de la militancia anarcosindicalista, cuyos habitantes, a través de la CNT, participaron en las largas huelgas de alquileres y, más tarde, en el proceso revolucionario que acompañó al golpe de estado de 1936. Posteriormente el barrio ha sido escenario de las transformaciones urbanas producto de las estrategia de acumulación de capital, que han afectado a la mayor parte de las ciudades contemporáneas. Portelli reconstruye la memoria del barrio y su sustrato socio-cultural para ofrecernos las claves para comprender los procesos de resistencia y las estrategias de los diferentes actores que entran en conflicto en este territorio.

El libro es el resultado del seguimiento etnográfico y personal de diez años (2002-2012) del proceso de derribo de las casas baratas en el marco de una investigación financiada por la Delegación de Cultura de la Generalitat de Catalunya, en colaboración con la asociación Avis del Barri de Bon Pastor (abuelos del barrio del Buen Pastor) surgida a raíz de las luchas vecinales. La investigación fue desarrollada por un equipo interdisciplinar 
liderado por Manuel Delgado (Universidad de Barcelona) y formado, junto con Portelli, por una antropóloga, Nuria Sánchez Armengol, una historiadora, Ulrike Viccaro, una arquitecta, Isabel Cadenas, y una habitante de las casas baratas, Sandra Capdevila Sardaña. La composición de este equipo explica, como se comprobará más adelante en cada capítulo del libro, el carácter poliédrico de la investigación, que combina descripciones etnográficas, fuentes orales y una cuidadosa búsqueda documental e historiográfica en archivos.

El concepto de ciudad horizontal que aparece en el título tiene un doble sentido. Por un lado, hace referencia a la forma horizontal que presenta el barrio estudiado, formado por casas bajas frente a los altos bloques de los edificios construidos dentro de los nuevos planes urbanísticos. Por otro lado, la horizontalidad no es sólo una característica arquitectónica que contrasta con la verticalidad de los nuevos edificios, a los que una parte de los vecinos se opone, sino que se debe, además, al carácter de las relaciones sociales, los vínculos comunitarios de sus habitantes. A la horizontalidad de los edificios le acompaña la horizontalidad social, las redes de apoyo mutuo, confianza, vida comunitaria, cuidados recíprocos, y reconocimientos. En este sentido el libro estudia a unos supervivientes culturales, que se enfrentan a su destino: el bulldozer urbanizador, conscientes de que el cambio radical en sus viviendas significará un cambio radical en su forma de vida. Una parte de los habitantes de Bon Pastor, en definitiva, se resistía a encajar en los procesos de individuación, de destrucción de la comunidad, que acompaña a lo que Bauman ha denominado la modernidad líquida. Los protagonistas de este libro tenían unos anclajes en el territorio, se apoyaban unos a otros, gestionaban internamente sus conflictos y se relacionaban entre sí como si se tratara de un organismo autónomo. Desde este prisma, Bon Pastor era una isla resistente en un mar de homogenización cultural, mercantilización y urbanismo neoliberal.

Una de las características del libro es la buena redacción de Portelli. A través de las descripciones etnográficas y los testimonios de los actores pacientemente recogidos y elaborados, el autor consigue trasladar el lector al barrio, imaginar sus calles, escuchar los cantes flamencos o incluso oler la madera quemada de las hogueras de San Juan. Describe, además, las situaciones, acontecimientos y vivencias huyendo de simplificaciones, juicios e idealizaciones, mostrando las contradicciones internas. En esto hace gala de esa honestidad científica que no está reñida con la intencionalidad política, y que ha faltado con frecuencia en los discursos periodístico, literario, político y administrativo sobre la ciudad y el barrio.

La obra está dividida en cinco capítulos además de la introducción y las conclusiones. El primer capítulo, titulado "Para una historia de las casas baratas", Portelli reconstruye a partir de fuentes documentales la historia del barrio desde sus orígenes hasta la actualidad. El pasado anarquista del barrio, fraguado en las luchas populares previas al 
golpe de estado de 1936, está presente a lo largo de toda la historia: en la posguerra, la dictadura, el movimiento vecinal durante la llamada Transición "democrática" e incluso ante la llegada al poder municipal del Partido Socialista.

El capítulo dos, "La misma historia desde dentro" explora la memoria colectiva sobre esos acontecimientos históricos a partir de los testimonios orales de los habitantes. El hambre, la lucha, la dignidad, la pobreza, la prosperidad, le represión, la felicidad, la exclusión, la familia, la comunidad, etc. son parte integrante de estas narrativas biográficas de los habitantes de Bon Pastor. El autor rescata estos relatos que conforman la memoria social compartida.

El capítulo tres, "Etnografía de Bon Pastor", describe el barrio y algunos aspectos de la vida cotidiana de los vecinos. Éstos forman una "gran familia" en el sentido de que presentan formas de sociabilidad propia de comunidades fuertemente integradas: charlar extensamente, tomar el fresco, vigilarse unos a otros... forman parte de las prácticas cotidianas que convierten al barrio en un "pueblo" dentro de una ciudad neoliberal. La vida social se desarrolla, sobre todo, en el espacio público (jugando al bingo, al parchís, cantando, tomando vermut, sentados en sillas de playa...). Aunque, dependiendo del nivel de confianza, algunas aspectos íntimos se desarrollan en el interior de las viviendas. Además, este tipo de vida favorece un férreo control social por parte de la comunidad: quién entra, quién sale, con quién, a qué horas... A través de un juego de miradas, de rumores, de "chafarderío" los vecinos activan estos mecanismos que sirven al mismo tiempo para la cohesión social y el apoyo mutuo. Estas prácticas también refuerzan el sentimiento de identificación, de familiaridad entre los habitantes y sus viviendas, un vínculo que explica el desarrollo de la acción colectiva contra la remodelación y la especulación urbanística. Portelli argumenta que los mitos (en especial el mito sobre el origen de los terrenos) sirven como armas discursivas en la disputa política, al ser re-significados y utilizados por los habitantes para legitimar sus intereses en juego. Las redes de solidaridad, además, han configurado un barrio en resistencia ante el abandono de las autoridades. A través de la lucha, históricamente los vecinos han conseguido de la administración infraestructuras y mejoras: escuelas, semáforo, parada de metro...

En el capítulo cuatro, titulado "La lucha contra la Remodelación", analiza la acción colectiva de los vecinos ante sucesivos intentos de destrucción del barrio. Una destrucción no sólo arquitectónica, sino de la compleja y densa red de relaciones sociales que lo componen. En la década de 1980, con la proclamación de Barcelona como sede de los Juegos Olímpicos de 1992 se abrió la puerta a la gentrificación en la ciudad, el desplazamiento de las clases populares del centro histórico. En la década de 1990, con la liberación del mercado inmobiliario subirían drásticamente los precios de las viviendas, favoreciendo el mobbing inmobiliario y la especulación. En 1998, a través de la prensa, se difunde el "discurso de la remodelación", construyendo una narrativa de legitimación de 
los proyectos urbanísticos de las autoridades rescatando el "mito negativo" del barrio y sus habitantes. En Bon Pastor la acción colectiva se inicia en 2003 a partir de una escisión de la Asociación de Vecinos que formó la agrupación Avis del Barri en defensa de las familias de Bon Pastor. Portelli describe en este capítulo los conflictos internos entre los dos sectores de la comunidad, el papel de los diferentes actores en la lucha, la acción colectiva, los desahucios, las ocupaciones, las negociaciones, e incluso la irrupción de agentes externos como el movimiento okupa o el ámbito académico.

En el quinto capítulo, "El impacto social de las transformaciones urbanas", explica cómo la transformación definitiva de un barrio de casas bajas en un bloque de pisos significó la "penetración de unos modelos de comportamiento tradicionalmente externos al barrio" (p. 349). La densa madeja de relaciones comunitarias que se configuraron históricamente a través del espacio desapareció radicalmente con la construcción de los bloques de pisos, que favorecen relaciones individualistas e impiden cualquier tipo de expresión comunitaria.

Para terminar esta reseña del excelente libro de Portelli quisiera destacar tres cuestiones que, a mi modo de ver, son las aportaciones más importantes. La primera se refiere a la importancia de las transformaciones urbanas en la configuración de las relaciones sociales. La actual hegemonía neoliberal, la desarticulación de los lazos comunitarios que vertebraban la lucha de clases, no puede ser entendida sin este tipo de procesos de "remodelación". La "destrucción creativa" que según Harvey define al neoliberalismo se refiere, en consecuencia, tanto a las ideas como a aspectos materiales y relacionales.

En segundo lugar, La ciudad horizontal describe la dificultad del movimiento okupa barcelonés para articularse con la lucha de los vecinos. Es un claro ejemplo de cómo la guetización permite construir identidades resistentes en entornos sociales hostiles, pero al mismo tiempo no permite desplegar estrategias de construcción de mayorías, de conectar con amplias capas sociales. La experiencia contada por el antropólogo invita a una urgente reflexión en el seno de los movimientos por el derecho a la vivienda, una reflexión que en parte ya se ha superado a partir de la creación de la Plataforma de Afectados por la Hipoteca.

Por último, quiero subrayar un debate que se encuentra presente a lo largo de todo el texto, aunque especialmente en la introducción y las conclusiones. Me refiero al tipo de investigación defendida por Portelli: la antropología comprometida, o engaged anthropology, que, sin renunciar al rigor del método científico, persigue además de una finalidad teórica, unos objetivos políticos comprometidos con valores democráticos y radicales. Esto implica revisar algunos presupuestos epistemológicos y metodológicos de la investigación convencional, optando por fórmulas de etnografía colaborativa, en la que los vecinos participan en la producción del conocimiento, bien formando parte del equipo de investigación, bien aportando testimonios, visiones y apreciaciones sobre 
los documentos escritos. El papel de la asociación comunitaria Avis de Bon Pastor en el proyecto refuerza el carácter colaborativo de esta investigación antropológica. Portelli define este tipo de antropología como una antropología horizontal: "el debate que proponemos sobre antropología horizontal se resume en un equilibrio entre la necesaria cientificidad de la investigación, y la no menos necesaria pasión política y proximidad humana de las personas involucradas" (p. 456). De este modo, la obra de Portelli constituye una buena plasmación del la fructífera combinación de orientación antropológica y pasión política que caracteriza al Grupo de Trabajo de Periferias Urbanas del Instituto Catalán de Antropología y al Observatori del Conflicte Urbà (OACU), de los que forma parte. 